\title{
Effect of Supplementation of Various Sources of Methionine on Serum Biochemical Properties in Broiler Chicken
}

\author{
B. Brahmaiah ${ }^{1 *}$, J.V. Ramana ${ }^{2}$, B. Devasena ${ }^{3}$ and G. Vijay Bhaskar Reddy ${ }^{4}$ \\ ${ }^{1}$ Department of Animal Nutrition, ${ }^{2}$ Controller of Examinations, ${ }^{3}$ Department of Livestock \\ Farm Complex, ${ }^{4}$ Department of Livestock Products Technology, College of Veterinary \\ Science, Tirupati, Sri Venkateswara Veterinary University, \\ Chittoor District, Andhra Pradesh, India \\ *Corresponding author
}

\begin{tabular}{|c|c|}
\hline & A B S T R A C T \\
\hline & \multirow{9}{*}{$\begin{array}{l}\text { An experiment was conducted to study the effect of various sources of Methionine on } \\
\text { growth performance and cost economics in broiler chicken. In a CRD model, } 375 \text { broiler } \\
\text { chicks (Vencobb) were randomly divided into five groups }\left(\mathrm{T}_{1}, \mathrm{~T}_{2}, \mathrm{~T}_{3}, \mathrm{~T}_{4} \text { and } \mathrm{T}_{5} \text { ), each }\right. \\
\text { containing } 3 \text { replicates with } 25 \text { birds in each replicate. The } \mathrm{T}_{1} \text { group served as control } \\
\text { group, } \mathrm{T}_{2} \text { group was supplemented with synthetic Methionine (Nutrient requirements of } \\
\text { ICAR } 2013), \mathrm{T}_{3} \text { and } \mathrm{T}_{4} \text { groups were supplemented with Methionine producing microbes } \\
\text { (MPM) and } \mathrm{T}_{5} \text { group was supplemented with combination of } \mathrm{T}_{2} \text { and } \mathrm{T}_{3} \text {, respectively for a } \\
\text { period of } 42 \text { days. The results of the experiment revealed that higher }(\mathrm{P}<0.01) \text { levels of } \\
\text { serum total protein }(\mathrm{g} / \mathrm{dl}) \text {, albumin }(\mathrm{g} / \mathrm{dl}) \text {, globulin }(\mathrm{g} / \mathrm{dl}) \text { and AST (IU/L) were observed in } \\
\text { synthetic Methionine }\left(\mathrm{T}_{2}\right) \text { supplemented group compared to other groups during the entire } \\
\text { experimental period. Whereas, broiler chicks in } \mathrm{T}_{3} \text { and } \mathrm{T}_{4} \text { groups showed lower }(\mathrm{P}<0.01) \\
\text { serum cholesterol }(\mathrm{mg} / \mathrm{dl}) \text { and higher }(\mathrm{P}<0.01) \text { serum glucose }(\mathrm{mg} / \mathrm{dl}) \text { levels. However } \\
\text { serum ALT (IU/L) levels were higher }(\mathrm{P}<0.01) \text { in control group as compared to other } \\
\text { groups. }\end{array}$} \\
\hline & \\
\hline & \\
\hline & \\
\hline & \\
\hline Articl & \\
\hline & \\
\hline & \\
\hline & \\
\hline
\end{tabular}

\section{Introduction}

Poultry industry in India is more scientific as compared with the rest of the livestock sectors. Among all essential amino acids Lysine and Methionine are considered as critical amino acids (FAO, 2010). Methionine is the most essential amino acid required for healthy and productive poultry and is usually considered as first limiting amino acid in cornsoya diets followed by Lysine and Arginine (NRC, 1994).
Methionine serves as a methyl donor for transmethylation reactions in the biosynthesis of lipids and lipid transport in the blood (Patterson and Kung, 1998). Methionine acts as a lipotropic agent through its role as an amino acid in balancing protein and as methyl donor and is involved in the metabolism of Choline, Betaine, Folic acid and Vitamin $\mathrm{B}_{12}$ (Young et al., 1955; March and Biely, 1956). Supplementation of Methionine to poultry diet has been corrected with tendency to have less 
body fat (Rostagno et al., 1995) to improve growth performance and reduce odour-related compound in excreta (Chavez et al., 2004). Methionine supplementation improves production performance through pathways of poly amine metabolism (Gonzalez-Esquerra and Leeson, 2006) and glutathione (derived from Methionine), which reduces the damage from oxidative stress.

The low concentration of Methionine in highprotein corn-soybean feed mixes has lead to wide use of DL- Methionine (Met) supplementation in poultry feeds (Anonymous, 1999; NOSBTAP Review. 2001). The most common source of Methionine in poultry diets is DL-Met produced by synthetic chemistry from acrolein, methyl mercaptan and hydrogen cyanide. The synthetic Methionine can be metabolized into highly toxic compounds such as methyl thiopropionate, thereby adversely altering the performance of poultry birds (Baker, 1991). Similarly, Methionine producing microbes have been isolated from soil and from various sources and screened for the amount of Methionine produced from the microorganisms (Thomas, 2014).

Keeping in view, the present investigation was carried out to study the effect of Methionine producing microbes (Bacillus subtilis, Corynebacterium glutamicum, Lactobacillus plantarum, Leuconostoc sp., Saccharomyces sake) live microbial cultures with a TVC of 6000 Million CFU/g. and synthetic Methionine in broiler diets. Methionine producing microbes (MPM) is an commercial by product supplied by M/s DVS BIOLIFE Pvt Ltd.

\section{Materials and Methods}

\section{Experimental location}

The present experiment was carried out at
Livestock Farm Complex, College of veterinary science Tirupati, Sri Venkateswara Veterinary University, Andhra Pradesh.

\section{Experimental design}

The present study was carried out with three hundred and seventy five, day old broiler chicks obtained from a local hatchery. These chicks were randomly allotted to five experimental groups with each group having three replicates and with twenty five birds per replicate in a Completely Randomized Design. The $\mathrm{T}_{1}$ group served as control group, $\mathrm{T}_{2}$ group was supplemented with synthetic Methionine (Nutrient requirements of ICAR 2013) $T_{3}$ and $T_{4}$ group were supplemented with MPM and the $\mathrm{T}_{5}$ group was supplemented with combination of $T_{2}$ and $T_{3}$ (half the dose of $T_{2}$ and $T_{3}$ ) respectively for a period of 42 days was presented in the Table 1 .

\section{Experimental diets}

The broiler diets were formulated in three phases i.e., pre-starter (0-14 days), starter (1528 days) and finisher (29-42 days). Basal diet was prepared as per the Nutrient requirements of Poultry ICAR (2013). Representative samples of experimental diets were analyzed for proximate composition as per AOAC (2005).

\section{Health management}

The chicks were vaccinated with HVT vaccine, $F_{1}$ vaccine, IBD vaccine and Lasota vaccine on the $1^{\text {st }}, 6^{\text {th }}, 14^{\text {th }}$ and $23^{\text {rd }}$ days respectively.

\section{Blood collection}

At the time of slaughter of the birds, blood samples were collected at the end of prestarter, starter and finisher phases from each 
bird and serum was separated to estimate serum metabolites. The separated serum was then made clear by centrifuging at 3000 RPM for 10 minutes and transferred to dry, clean epindorf tubes and stored in a refrigerator at ($20^{\circ} \mathrm{c}$ ) for estimation of serum parameters.

\section{Serum analysis}

The serum biochemical profile of experimental broiler chicks were assessed at the end of each phase. Total protein, albumin, globulin, glucose, cholesterol, Aspartate transaminase (AST) and Alanine transaminase (ALT) levels were estimated colorimetrically using diagnostic kit (SPAN diagnostic Ltd.,) by kinetic assay method.

\section{Analysis of data}

The data obtained was subjected to one- way ANOVA. Differences between means were tested at the $1 \%$ probability level using Duncan's LSD test. All the statistical analysis were done using SPSS programmer version 16 (SPSS, Richmond, VA, USA) as described by DYtham (2011).

\section{Results and Discussion}

All the serum biochemical parameters during Pre-starter, starter and finisher phases of growth period were estimated and presented in the Table 2, 3 and 4.

The results of the current study revealed that, serum total protein $(\mathrm{g} / \mathrm{dl})$, serum albumin $(\mathrm{g} / \mathrm{dl})$ and serum globulin $(\mathrm{g} / \mathrm{dl})$ were found to be higher $(\mathrm{P}<0.01)$ in broilers supplemented with synthetic Methionine $\left(\mathrm{T}_{2}\right)$ group as compared to other groups. This might be due to supplementation of synthetic Methionine leads to increased protein biosynthesis (Fancher and Jensen, 1987). The results were in agreement with Ahmed mujahid (2005) who reported that increased levels of serum total protein, albumin and globulin in broilers were observed with synthetic Methionine supplementation.

Serum Cholesterol (mg/dl) levels was significantly lower $(\mathrm{P}<0.01)$ and serum glucose $(\mathrm{mg} / \mathrm{dl})$ was significantly higher $(\mathrm{P}<0.01)$ in Methionine treated groups compared to control group. This might be due to Methionine act as methyl donor and influences cholesterol metabolism (Scott et al., 1982). This may be advantageous to humans as meat from these birds will reduce cholesterol intake. The findings of Abdel Rahman (2000) and Kiran Kumari et al., (2012) also revealed lower cholesterol levels in serum were noticed in synthetic Methionine supplemented group.

Table.1 Inclusion levels of synthetic Methionine, MPM and combination (gram/ton of feed) at various phases of growth in broiler chicken

\begin{tabular}{|l|c|c|c|c|c|}
\hline \multicolumn{1}{|c|}{ Phases } & $\mathrm{T}_{1}$ & $\mathrm{~T}_{2}$ & $\mathrm{~T}_{3}$ & $\mathrm{~T}_{4}$ & $\mathrm{~T}_{5}\left(\mathrm{~T}_{2}+\mathrm{T}_{3}\right)$ \\
\hline $\begin{array}{l}\text { Pre-starter (0-14 } \\
\text { days) }\end{array}$ & - & 2000 & 500 & 1000 & $1000+250$ \\
\hline Starter (15-28 days) & - & 1700 & 500 & 1000 & $850+250$ \\
\hline $\begin{array}{l}\text { Finisher (29-42 } \\
\text { days) }\end{array}$ & - & 1300 & 500 & 1000 & $650+250$ \\
\hline
\end{tabular}


Table. 2 The Mean \pm SE and analysis of variance of serum biochemical parameters in broilers supplemented with various sources of Methionine in diet during Pre-starter phase

\begin{tabular}{|c|c|c|c|c|c|}
\hline \multirow{2}{*}{$\begin{array}{c}\text { Serum } \\
\text { biochemical } \\
\text { parameters** }\end{array}$} & \multicolumn{5}{|c|}{ Treatments } \\
\hline & $\mathbf{T}_{1}$ & $\mathbf{T}_{2}$ & $\mathbf{T}_{\mathbf{3}}$ & $\mathbf{T}_{4}$ & $\mathbf{T}_{5}$ \\
\hline $\begin{array}{c}\text { Total Protein } \\
\text { (g/dl) }\end{array}$ & $3.69 \pm 0.14^{b}$ & $4.81 \pm 0.07^{\mathrm{a}}$ & $3.78 \pm 0.17^{b}$ & $3.72 \pm 0.41^{b}$ & $4.02 \pm 0.52^{\mathrm{ab}}$ \\
\hline $\begin{array}{l}\text { Albumin } \\
\text { (g/dl) }\end{array}$ & $2.43 \pm 0.08^{b}$ & $2.95 \pm 0.10^{\mathrm{a}}$ & $2.45 \pm 0.28^{\mathrm{ab}}$ & $2.41 \pm 0.09^{\mathrm{ab}}$ & $2.44 \pm 0.60^{\mathrm{ab}}$ \\
\hline $\begin{array}{l}\text { Globulin } \\
\text { (g/dl) }\end{array}$ & $1.26 \pm 0.02^{c}$ & $1.86 \pm 0.07^{\mathrm{a}}$ & $1.33 \pm 0.10^{b}$ & $1.31 \pm 0.08^{b}$ & $1.58 \pm 0.12^{\mathrm{ab}}$ \\
\hline $\begin{array}{c}\text { Cholesterol } \\
\text { (mg/dl) }\end{array}$ & $175.40 \pm 1.01^{\mathrm{a}}$ & $177.22 \pm 1.07^{\mathrm{a}}$ & $130.24 \pm 2.06^{b}$ & $133.86 \pm 1.09^{b}$ & $175.22 \pm 1.65^{\mathrm{a}}$ \\
\hline $\begin{array}{l}\text { Glucose } \\
\text { (mg/dl) }\end{array}$ & $179.02 \pm 2.35^{b}$ & $177.2 \pm 1.98^{\mathrm{b}}$ & $195.59 \pm 2.04^{\mathrm{a}}$ & $197.02 \pm 3.01^{\mathrm{a}}$ & $176.99 \pm 1.14^{b}$ \\
\hline AST (IU/L) & $107.94 \pm 2.01^{\mathrm{ab}}$ & $109.55 \pm 2.21^{\mathrm{a}}$ & $106.97 \pm 1.19^{b}$ & $106.72 \pm 2.51^{b}$ & $108.27 \pm 3.58^{\mathrm{ab}}$ \\
\hline ALT (IU/L) & $6.24 \pm 0.24^{\mathrm{a}}$ & $4.85 \pm 0.37^{\mathrm{ab}}$ & $4.13 \pm 0.09^{b}$ & $4.26 \pm 0.41^{b}$ & $4.81 \pm 0.50^{\mathrm{ab}}$ \\
\hline
\end{tabular}

${ }^{a b c}$ Values in a row bearing different superscripts differ significantly $* *(\mathrm{P}<0.01)$

Table.3 The Mean \pm SE and analysis of variance of serum biochemical parameters in broilers supplemented with various sources of Methionine in diet during starter phase

\begin{tabular}{|c|c|c|c|c|c|}
\hline \multirow{2}{*}{$\begin{array}{c}\text { Serum } \\
\text { biochemical } \\
\text { parameters** }\end{array}$} & \multicolumn{5}{|c|}{ Treatments } \\
\hline & $\mathbf{T}_{1}$ & $\mathbf{T}_{2}$ & $\mathbf{T}_{\mathbf{3}}$ & $\mathbf{T}_{4}$ & $\mathbf{T}_{5}$ \\
\hline $\begin{array}{l}\text { Total Protein } \\
\text { (g/dl) }\end{array}$ & $3.51 \pm 0.23^{b}$ & $4.31 \pm 0.18^{\mathrm{a}}$ & $3.54 \pm 0.38^{\mathrm{b}}$ & $3.58 \pm 0.24^{b}$ & $3.95 \pm 0.18^{\mathrm{ab}}$ \\
\hline $\begin{array}{l}\text { Albumin } \\
\text { (g/dl) }\end{array}$ & $2.02 \pm 0.14^{b}$ & $2.26 \pm 0.09^{\mathrm{a}}$ & $2.08 \pm 0.27^{b}$ & $2.04 \pm 0.08^{b}$ & $2.03 \pm 0.12^{b}$ \\
\hline $\begin{array}{l}\text { Globulin } \\
\text { (g/dl) }\end{array}$ & $1.49 \pm 0.21^{\mathrm{c}}$ & $2.05 \pm 0.05^{\mathrm{a}}$ & $1.46 \pm 0.11^{\mathrm{c}}$ & $1.54 \pm 0.15^{\mathrm{c}}$ & $1.92 \pm 0.09^{b}$ \\
\hline $\begin{array}{l}\text { Cholesterol } \\
\text { (mg/dl) }\end{array}$ & $114.47 \pm 2.54^{b}$ & $118.67 \pm 3.41^{\mathrm{a}}$ & $99.68 \pm 1.89^{c}$ & $100.27 \pm 2.09^{c}$ & $114.26 \pm 1.78^{b}$ \\
\hline $\begin{array}{l}\text { Glucose } \\
\text { (mg/dl) }\end{array}$ & $110.02 \pm 1.01^{b}$ & $112.33 \pm 0.92^{b}$ & $126.66 \pm 1.87^{a}$ & $125.66 \pm 0.89^{a}$ & $113.02 \pm 0.68^{b}$ \\
\hline AST (IU/L) & $153.92 \pm 1.14^{\mathrm{ab}}$ & $154.71 \pm 1.34^{\mathrm{a}}$ & $151.71 \pm 2.08^{\mathrm{b}}$ & $152.71 \pm 3.01^{b}$ & $153.28 \pm 2.23^{\mathrm{ab}}$ \\
\hline ALT (IU/L) & $10.66 \pm 0.57^{\mathrm{a}}$ & $7.59 \pm 0.18^{c}$ & $8.01 \pm 0.24^{b}$ & $8.75 \pm 0.21^{\mathrm{ab}}$ & $7.88 \pm 0.31^{b}$ \\
\hline
\end{tabular}


Table.4 The Mean \pm SE and analysis of variance of serum biochemical parameters in broilers supplemented with various sources of Methionine in diet during Finisher phase

\begin{tabular}{|c|c|c|c|c|c|}
\hline \multirow{2}{*}{$\begin{array}{c}\text { Serum } \\
\text { biochemical } \\
\text { parameters } * *\end{array}$} & \multicolumn{5}{|c|}{ Treatments } \\
\hline & $\mathbf{T}_{1}$ & $\mathbf{T}_{2}$ & $\mathbf{T}_{3}$ & $\mathbf{T}_{4}$ & $\mathbf{T}_{5}$ \\
\hline $\begin{array}{l}\text { Total Protein } \\
\text { (g/dl) }\end{array}$ & $3.24 \pm 0.17^{\mathrm{c}}$ & $4.09 \pm 0.50^{\mathrm{a}}$ & $3.21 \pm 0.37^{\mathrm{c}}$ & $3.26 \pm 0.26^{\mathrm{c}}$ & $3.78 \pm 0.11^{b}$ \\
\hline $\begin{array}{c}\text { Albumin } \\
\text { (g/dl) }\end{array}$ & $1.53 \pm 0.16^{\mathrm{b}}$ & $1.730 .28^{\mathrm{a}}$ & $1.55 \pm 0.91^{b}$ & $1.56 \pm 0.14^{b}$ & $1.50 \pm 0.07^{b}$ \\
\hline $\begin{array}{l}\text { Globulin } \\
\text { (g/dl) }\end{array}$ & $1.71 \pm 0.04^{b}$ & $2.36 \pm 0.07^{\mathrm{a}}$ & $1.66 \pm 0.16^{b}$ & $1.70 \pm 0.20^{b}$ & $2.28 \pm 0.13^{\mathrm{a}}$ \\
\hline $\begin{array}{l}\text { Cholesterol } \\
\text { (mg/dl) }\end{array}$ & $115.59 \pm 1.29^{\mathrm{ab}}$ & $120.31 \pm 1.34^{\mathrm{a}}$ & $105.42 \pm 0.98^{b}$ & $106.29 \pm 2.48^{b}$ & $115.08 \pm 2.01^{\mathrm{ab}}$ \\
\hline $\begin{array}{l}\text { Glucose } \\
(\mathrm{mg} / \mathrm{dl})\end{array}$ & $91.87 \pm 1.01^{b}$ & $91.57 \pm 1.53^{b}$ & $113.28 \pm 1.69^{\mathrm{a}}$ & $114.16 \pm 0.57^{\mathrm{a}}$ & $92.50 \pm 1.59^{b}$ \\
\hline AST (IU/L) & $184.92 \pm 3.25^{b}$ & $186.83 \pm 1.47^{\mathrm{a}}$ & $183.70 \pm 2.58^{\mathrm{c}}$ & $183.67 \pm 3.69^{c}$ & $185.95 \pm 3.57^{\mathrm{ab}}$ \\
\hline ALT (IU/L) & $16.63 \pm 0.07^{\mathrm{a}}$ & $12.87 \pm 0.48^{c}$ & $13.37 \pm 0.24^{b}$ & $13.26 \pm 0.09^{b}$ & $12.04 \pm 0.58^{c}$ \\
\hline
\end{tabular}

${ }^{a b c}$ Values in a row bearing different superscripts differ significantly $* *(\mathrm{P}<0.01)$

Serum AST (IU/L) was significantly $(\mathrm{P}<0.01)$ higher in synthetic Methionine supplemented group and serum ALT (IU/L) was significantly $(\mathrm{P}<0.01)$ higher in control group. The results were not in agreement with Ahmed mujahid (2005) who reported that, decreased serum AST levels was observed in Methionine supplemented diets. While Kiran Kumari et al., (2012) reported non-significant difference in serum AST (IU/L) and ALT (IU/L) between herbal and synthetic Methionine supplemented groups.

Based on the present results it can be concluded that dietary supplementation of MPM fed alone can reduce the cholesterol content of the serum in broilers and it appears to be beneficial from the human health point of view.

\section{References}

Abdel Rahman, B. M. D. 2005. Effect of Dietary Choline and Methionine on Broiler Chicks Performance and Some Blood Parameters. M.Sc. thesis in
Nutritional science. University of Khartoum.

Ahmed Mujahid. 2005. Recent advances in methionine nutrition for poultry. $\mathrm{Br}$. Poult Sci. 41:83-88; Int. J. Poult Sci, 4:856-865.

Anonymous, 1999. Organic production of agricultural products and indications referring there to on agricultural products and food stuffs to include livestock products. Official Journal of European Committees EU council regulation. 104/1999:22.

AOAC, 2005. Official Methods of Analysis of the Association of Official Analytical Chemists. 15th Edition, Washington, D.C.

Baker, D. H. 1991. Amino acid tolerances of swine and poultry. Washington, DC: NFIA. Nutrition Institute handbook.

Chavez, C., Coufal, C. D., Niemeyer, P. L., Carey, J. B., Lacey, R. E., Miller, R. K. and Beier, R. C. 2004. Impact of dietary supplemental methionine sources on sensory measurement of odor-related 
compounds in broiler excreta. Poultry Science. 83:1655-1662.

DYtham, C. 2011. Choosing and Using Statistics: A Biologist's Guide. 3rd edition. Whiley-Blackwell Ltd., London, UK.

Fancher, B. I. and Jenson, L. S. 1987. Influence on performance of three to 6 weeks old broilers of varying dietary protein contents with supplementation of essential amino acids requirements. Poult. Sci. 68: 113-123.

FAO 2010. Smallholder Poultry Production Livelihoods, Food Security and Sociocultural Significance, by K. N. Kryger, K. A. Thomsen, M. A. Whyte and M. Dissing. FAO Smallholder Poultry Production Paper No. 4. Rome.

Gonzalez-Esquerra, R. and Leeson, S. 2006. Physiological and metabolic responses of broilers to heat stress-implications for protien and acid nutrition. Journal of Worlds Poultry Science. 62: 282-595.

Kiran Kumari, Tiwari, S. P., Subhankar Nanda, Saxena, M. J., Ravikanth, k. and ShiviMaini. 2012. Studies on Comparative Efficacy of Herbal Amino Acid (Methiorep) Supplement with Synthetic Dl Methionine on Broiler Growth Performance and Carcass Quality Traits. International Journal of Scientific and Research Publications. 2: $1-6$.

March, B. and Biely, J. 1956. Folic acid supplementation of high protein-high fat diets. Poultry Science. 35: 550-551.
National Organic Standards Board Technical Advisory Panel (NOSBTAP) Review, 2001. Compiled by Organic Materials Review Institute for the USDA National Organic Programme. 1-20.

National Research Council (NRC). 1994. Nutrient Requirements of Poultry. $9^{\text {th }}$ Edition. National Academy Press, Washington DC, USA.

Patterson, J. A. and Kung, L. 1998. Metabolism of DL-methionine analogue by rumen microorganisms. Journal of Diary Science. 71: 3292-3301.

Rostagno, H. S., Pupa, J. M. R. and Pack, M. 1995. Diet formulation for broilers based on total versus digestible amino acids. The Journal of Applied Poultry Research. 4:293-299.

Scott, M. L. Nesheim, M. C. and Young, R. J. (1982). Choline in nutrition of the chicken. Third edition. pp. 243-251. Scott, M. L. and association publishers, J. Thaca, N. Y.

Thomas willke. 2014. Methionine production - a critical review. Applied Microbiology and Biotechnology. Springer-Verlag Berlin Heidelberg.

Young, R. J., Norris, L. C. and Heuser, G. F. 1955. The chick's requirement for folic acid in the utilization of choline and its precursors betaine and methyl amino ethanol. Journal of Nutrition. 55: $535-362$.

\section{How to cite this article:}

Brahmaiah, B., J.V. Ramana, B. Devasena and Vijay Bhaskar Reddy, G. 2018. Effect of Supplementation of Various Sources of Methionine on Serum Biochemical Properties in Broiler Chicken. Int.J.Curr.Microbiol.App.Sci. 7(11): 871-876. doi: https://doi.org/10.20546/ijcmas.2018.711.103 